\title{
Heterotopic Ossification in the Cervical Total Disc Replacement with Discover Prostheses: A Retrospective 5-Year Follow-Up Study
}

\author{
Giuseppe Maida ${ }^{1 *}$, Pipino Gennaro ${ }^{2}$ and Eleonora Marcati ${ }^{3}$ \\ ${ }^{1}$ Division of Spine Surgery, Santa Maria Maddalena Clinic 1, Rovigo, Italy \\ ${ }^{2}$ Complex Unit-Departments of Orthopaedics and Traumatology, Villa Regina Hospital 115, Bologna, Italy \\ ${ }^{3}$ Division of Neurosurgery, Department of Neuroscience and Rehabilitation, University-Hospital S. Anna 8, Ferrara, Italy
}

\begin{abstract}
Study background: Heterotopic ossification $(\mathrm{HO})$ is a well-known complication of cervical total disc replacement (CTDR), a successful alternative to cervical decompression and fusion for degenerative disc disease.
\end{abstract}

Objective: The aim of our study was to evaluate the incidence of $\mathrm{HO}$ in single and double-level Discover disc replacement, a relatively new type of artificial implants. Moreover, the related clinical and radiological outcomes and the possible influencing factors were analysed.

Methods: Twenty-six women and 39 men were retrospectively followed-up for 5 years. They consecutively underwent one or two-level cervical Discover arthroplasty. Clinical outcome was assessed using the visual analogue scale (VAS). The angular range of motion (ROM) was calculated with periodic dynamic X-rays. A Student's t test was used to analyse the association between the occurrence of $\mathrm{HO}$ and various risk factors.

Results: Among the 65 patients enrolled, the overall incidence of $\mathrm{HO}$ was $7.69 \%$ and the mean follow-up was $63.29 \pm 11.90$ months. All the cases were diagnosed as Grade III or Grade IV. The mean VAS showed immediate postoperative improvements and the mean ROM was partially maintained. No displacement of the prostheses was detected.

Conclusions: During the 5-year follow-up period, the Discover cervical discs have provided optimal clinical outcomes showing a lower and tardive incidence of $\mathrm{HO}$ than other reported implants. Although a longer follow-up with a larger group of patients should be investigated, cervical arthroplasty can be still considered a safe and effective procedure in highly selected patients.

Keywords: Cervical disc replacement; Discover disc; Arthroplasty; Heterotopic ossification

\section{Introduction}

Cervical Total Disc Replacement (CTDR) is a relatively new procedure whose main goal is to overcome the limitations of the anterior cervical discectomy and interbody fusion (ACDF), a successful treatment for degenerative cervical disc disease when not responding to medical therapy $[1,2]$. The main shortcomings of ACDF are the postoperative reduced range of motion (ROM) and the increased mechanical stress on adjacent vertebrae. In fact, the subsequent adjacent segment degeneration (ASD) has been reported to require a secondary surgery in 7-15\% of the cases [3-5]. Bryan, ProDisc-C, and Prestige are some of the previous most widely used disc replacement devices and their clinical and biomechanical outcomes have already been well-documented [6-13].

Heterotopic ossification (HO) after CTDR is more and more often described and it seems not to be related to the presence of muscular tissue, as in hip and knee arthroplasties [14]. Although its pathogenesis is still unclear, many authors associated it to both systemic and local factors [15]. Reidel et al. [16] first described this phenomenon in 1883 and subsequently it was noted in spinal cord injuries. Ever since, many authors reported $\mathrm{HO}$ as one of the main complications in dynamic cervical and lumbar implants [16-25]. In addition, our group published a rare case of $\mathrm{HO}$ secondary to an interspinous/interlaminar device [26].

It has been recently shown a low incidence of $\mathrm{HO}$ with a relatively short mean follow-up (31.6 months) on 79 patients treated with Discover artificial disc (DePuy Spine, Raynham, MA, USA) [27]. Our study aims to retrospectively analyse the outcome of Discover CTDR, particularly referring to heterotopic ossification with a longer follow-up.

\section{Materials and Methods}

\section{Patient population}

Sixty-five consecutive patients who underwent one or two-level CTDR with Discover prosthesis were enrolled in the study from January 2007 to October 2012. Inclusion criteria were subaxial (C3C7) disc herniation, degenerative disc disease (DDD) or spondylosis with radiculopathy and/or myelopathy, not responding to 6-month conservative treatments. Exclusion criteria included infection, tumour, osteoporosis, metabolic disease, ossification of the posterior longitudinal ligament (OPLL), disc height $<4 \mathrm{~mm}$, ligament injury or segmental instability, and kyphotic deformity. Preoperatively, all patients underwent dynamic cervical radiography, magnetic resonance imaging (MRI), and clinical evaluation using visual analogue scale (VAS). Preserved ROM was documented preoperatively and it was calculated as the difference between the angles obtained in the flexion and extension X-rays, as reported by Lee et al. [24]. The study was performed in accordance with the Helsinki Declaration and a prior informed consent was obtained from all the patients.

*Corresponding author: Giuseppe Maida, Division of Spine Surgery, Santa Maria Maddalena Clinic 1, Via Gorizia, 45030 Occhiobello, Rovigo, Italy, Tel: 0039 3479697287; Fax: 0039-0532247274; E-mail: giuma@vodafone.it

Received October 13, 2014; Accepted November 17, 2014; Published November 19, 2014

Citation: Maida G, Gennaro P, Marcati E (2014) Heterotopic Ossification in the Cervical Total Disc Replacement with Discover Prostheses: A Retrospective 5-Year Follow-Up Study. J Spine 3: 194. doi:10.4172/2165-7939.1000194

Copyright: $\odot 2014$ Maida G, et al. This is an open-access article distributed under the terms of the Creative Commons Attribution License, which permits unrestricted use, distribution, and reproduction in any medium, provided the original author and source are credited. 
Citation: Maida G, Gennaro P, Marcati E (2014) Heterotopic Ossification in the Cervical Total Disc Replacement with Discover Prostheses: A Retrospective 5-Year Follow-Up Study. J Spine 3: 194. doi:10.4172/2165-7939.1000194

Page 2 of 4

\section{Surgical technique}

In all cases, a right anterior cervical approach was performed as described by Smith and Robinson and a Discover artificial disc was implanted after a proper discectomy and removal of posterior longitudinal ligament and anterior osteophytes [28]. A lateral and anterior-posterior fluoroscopy was used intraoperatively to confirm the proper device positioning. An abundant irrigation with saline solution was performed during the entire procedure until the end of the wound closure. If not contraindicated, non-steroid anti-inflammatory drugs (NSAIDs) were routinely prescribed in the first two postoperative weeks. Each patient was precociously mobilised without neck collar and dismissed the first day after surgery. After a first evaluation at 30 days, all the patients were followed with annual clinical assessments and dynamic radiographies (Figure 1). Where $\mathrm{HO}$ was described, the following associations were analysed: age, sex, treated pathology, and number of levels. Moreover, HO was described using the McAfee's Classification (Table 1) and the flexion and extension ROM was measured after its appearance [29].

\section{Statistical analysis}

All statistical analyses were performed using SPSS software 17.0 (SPSS, Inc., Chicago, IL, USA). Radiological and clinical measurements were expressed as mean \pm standard deviation (SD). A Student's $t$ test was used to assess the statistical significance of postoperative VAS and overall ROM changes and to analyse the associations between the occurrence of $\mathrm{HO}$ and the influencing factors, including age, sex, number of levels, and treated pathology. $\mathrm{P}<0.05$ was considered as statistically significant.

\section{Results}

A total of 65 patients were enrolled in our study (26 men and 39 women). The mean patient age was $43.74 \pm 10.94$ years (range: $28-67$ years) and the mean follow-up was $63.29 \pm 11.90$ months (range: 14-83 months). Among the 65 implanted patients, 61 (93.84\%) were monosegments and 4 (6.15\%) were bi-segments. No prosthesis displacement and no revision surgery were observed in all the population. At the first

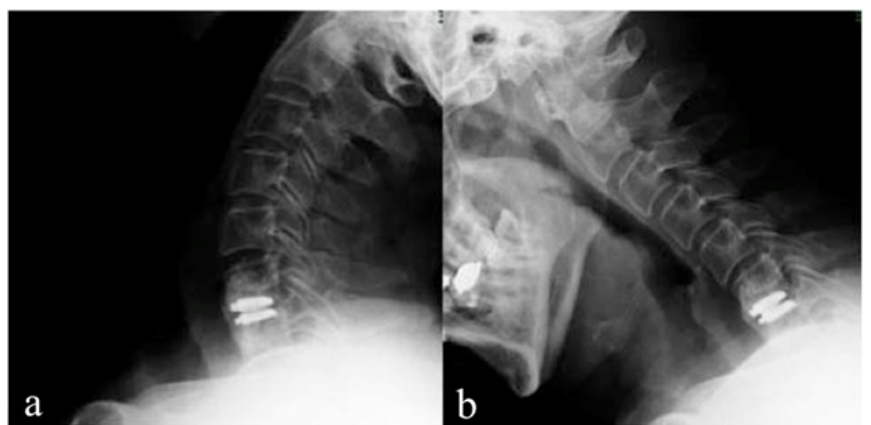

Figure 1: Flexion (a) and extension (b) X-ray after the occurrence of heterotopic ossification.

\begin{tabular}{|r|l|}
\hline \multicolumn{2}{|c|}{ McAfee's Classification } \\
\hline $\mathbf{0}$ & No HO \\
\hline I & $\begin{array}{l}\text { Islands of bone not within the margins of the disc and not interfering with } \\
\text { motion }\end{array}$ \\
\hline II & Bone within the margins of the disc but not blocking motion \\
\hline III & $\begin{array}{l}\text { Bone within the margins of the disc and interfering with motion of the } \\
\text { prosthesis }\end{array}$ \\
\hline IV & Bony ankylosis \\
\hline
\end{tabular}

Table 1: McAfee's Classification of Heterotopic Ossification (HO).

\begin{tabular}{|c|c|}
\hline Features & Number \\
\hline Patients & 65 \\
\hline Sex: M/F & $26 / 39$ \\
\hline Mean age & $43.7 \pm 10.94(28-54)$ \\
\hline Mean follow-up & $63.29 \pm 11.90(14-83)$ \\
\hline Mean preoperative VAS & $8.20 \pm 0.84$ \\
\hline Mean postoperative VAS & $2.20 \pm 1.30$ \\
\hline
\end{tabular}

Table 2: Patients' population.

\begin{tabular}{|c|c|c|c|c|c|}
\hline Patient & Sex, Age & Level & Pathology & Follow-up & $\begin{array}{c}\text { McAfee } \\
\text { degree of HO }\end{array}$ \\
\hline 1 & F, 41 yrs & $\begin{array}{l}\text { C5-C6 } \\
\text { C6-C7 }\end{array}$ & Soft herniation & 3 yrs & III \\
\hline 2 & F, 34 yrs & C6-C7 & Soft herniation & 5 yrs & III \\
\hline 3 & F, 42 yrs & C5-C6 & Soft herniation & 3 yrs & III \\
\hline 4 & M, 67 yrs & C6-C7 & Hard herniation & 3 yrs & III \\
\hline 5 & M,59 yrs & C5-C6 & Hard/Soft herniation & 5 yrs & IV \\
\hline
\end{tabular}

Table 3: Distribution of heterotopic ossification in the affected patients.

postoperative evaluation, the clinical outcome was improved with a mean decrease of the VAS Score from $8.20 \pm 0.84$ to $2.20 \pm 1.30$ (Table 2). Heterotopic ossification was noted in 5 patients $(7.69 \%)$ : two patients $(3.08 \%)$ at the 3 -year follow-up and 3 patients $(4.61 \%)$ at the 5 -year follow-up. Among them, only 1 patient (1.54\%) was symptomatic at the end of the follow-up and his major complaint was neck pain. Four of those cases (6.15\%) were Grade III of the McAfee's Classification with a residual maintenance of motion while 1 patient (1.54\%) was classified as Grade IV with a complete list of motion. The involved levels were all C5-C6 (40\%) and C6-C7 (60\%) (Table 3) where the operated levels were mostly C5-C6 and C6-C7 (49.23 and 38.09\%, respectively). The occurrence of $\mathrm{HO}$ was not significantly related to the concerned risk factors.

\section{Discussion}

The efficacy of CTDR has been widely reported over the past 10 years with a better protection of adjacent segments than ACDF. This feature is still debated, however a recent prospective study concluded that maintaining motion rather than fusion would prevent ASD [30,31]. Indeed, the preservation of motion constitutes the main goal of CTDR along with the maintenance of cervical lordosis, which some authors considered even more relevant to prevent the ASD after CTDR surgery [32,33]. Although most of the commonly used prostheses do not obtain the restoration of the cervical lordosis, the relatively new Discover discs have been described as MRI-compatible ball-and-socket devices, allowing all the directions and restoring the alignment in the cervical region $[27,34,35]$. Moreover, in patients who underwent CTDR it has been analysed the correlation between preoperative and postoperative ROM considering a poor preoperative ROM as a relative contraindication [36]. Instead, a preoperative disc height over $4 \mathrm{~mm}$ and the resection of posterior longitudinal ligament have been reported as favouring factors for a better ROM after CTDR [37]. Indeed, in the present study all the enrolled patients showed a preserved preoperative ROM and a disc height higher than $4 \mathrm{~mm}$.

Several studies analysed the incidence of $\mathrm{HO}$ and the related risk factors as one of the most important causes of limited motion after arthroplasties [38]. This phenomenon has been described as an ectopic bone formation around the implant, subsequent to the transformation of primitive cells into osteogenic cells or bone morphogenic protein [39,40]. It was first reported in 2005 when Parkinson published a case of fusion after Bryan disc implant at the C5-C6 level [41]. Nowadays, HO after CTDR is commonly described in the literature and its incidence 
varies widely. Significantly higher rates were noted in male sex, older age, multi-level surgery, presence of bone dust, stress between endplate and prosthesis $[19,24,39]$. Besides, the postoperative NSAIDs use has been considered to reduce $\mathrm{HO}$ formation and fusion rate. For instance, a study published by Heller et al. showed no spontaneous fusion at 2 years with the prescription of NSAIDs for 2 weeks postoperatively [42]. Consequently, a 2-week postoperative NSAIDs treatment was routinely used as prophylaxis.

Moreover, as the presence of bone dust has been widely considered as favouring factors of $\mathrm{HO}$, the removal of anterior osteophytes and the irrigation of the surgical field with abundant saline solution before the insertion of the device were considered mandatory in our series [39]. Furthermore, as a postoperative limitation of motion is considered to affect the occurrence of $\mathrm{HO}$, we decided to early mobilise the patients without neck collar [19]. Thus, we added to our surgical technique all those practical details, which were considered as factors lessening the risk of $\mathrm{HO}$ appearance.

In addition, it has been reported the important role of prosthesis type on the occurrence of $\mathrm{HO}$ with a greater incidence in PCM discs (80\%) and a lower rate in Bryan implants (49\%), with also a lower McAfee's Grade in this latter type [19,43]. A recent paper on ProDisc-C found a $37 \%$ rate of $\mathrm{HO}$, easily comparable to previously published studies on the same prosthesis $[11,44]$.

Most of the previous studies documented a progressive increase of the incidence and grade of $\mathrm{HO}$ as the time passes. The possibility of a plateau after the fourth year of follow-up has been hypothesised because the increase of the bone formation would decrease the ROM as far as the complete fusion is obtained [11,44,45]. In our study, all the patients showed the appearance of $\mathrm{HO}$ after the third year of follow-up and all of them were high McAfee's grade. Therefore, our rate of $\mathrm{HO}$ development was significantly lower than in previous reports, but more severe, although most of the enrolled patients had excellent clinical outcomes. Only 1 patient showed a high-grade HO (Grade IV) with a complete list of motion and in this case the functional result was the same as an ACDF. Similarly, Malham et al. [11] in his long-term followup study observed a late presentation of $\mathrm{HO}$, with no case identified at 2 years. Indeed, as described by Tu et al. [46] a CT scan could be crucial for the diagnosis of lower grade of $\mathrm{HO}$ and to better clarify the role of $\mathrm{HO}$ in the natural history of the CTDR.

In conclusion, our paper showed a lower rate of $\mathrm{HO}$ with a higher follow-up in respect with previous studies confirming that the use of a well-selected CTDR in the right patient, with a good positioning of the prostheses and a precise surgical technique, is still a safe, satisfactory, and effective procedure.

However, a prospective cohort study with at least a 10-year follow-up using multi-planar CT scans could overcome some of the shortcomings of this study. Furthermore, more examiners with a calculated interobserver agreement could be useful to obtain more reliable results.

\section{Conflict of Interest}

The authors report neither conflict of interest concerning the methods used in this study or personal financial or institutional interests in any of the drugs, materials or implants described in this paper.

\section{References}

1. Fraser JF, Härtl R (2007) Anterior approaches to fusion of the cervical spine: a metaanalysis of fusion rates. J Neurosurg Spine 6: 298-303.

2. Mummaneni PV, Burkus JK, Haid RW, Traynelis VC, Zdeblick TA (2007) Clinica and radiographic analysis of cervical disc arthroplasty compared with allograft fusion: a randomized controlled clinical trial. J Neurosurg Spine 6: 198-209.
3. Eck JC, Humphreys SC, Lim TH, Jeong ST, Kim JG, et al. (2002) Biomechanica study on the effect of cervical spine fusion on adjacent-level intradiscal pressure and segmental motion. Spine (Phila Pa 1976) 27: 2431-2434

4. Geisler FH, Caspar W, Pitzen T, Johnson TA (1998) Reoperation in patients after anterior cervical plate stabilization in degenerative disease. Spine (Phila Pa 1976) 23: 911-920.

5. Hilibrand AS, Carlson GD, Palumbo MA, Jones PK, Bohlman HH (1999) Radiculopathy and myelopathy at segments adjacent to the site of a previous anterior cervical arthrodesis. J Bone Joint Surg Am 81: 519-528.

6. Kim SW, Limson MA, Kim SB, Arbatin JJ, Chang KY, et al. (2009) Comparison of radiographic changes after ACDF versus Bryan disc arthroplasty in single and bi-level cases. Eur Spine J 18: 218-231.

7. Chang UK, Kim DH, Lee MC, Willenberg R, Kim SH, et al. (2007) Range of motion change after cervical arthroplasty with ProDisc-C and prestige artificial discs compared with anterior cervical discectomy and fusion. J Neurosurg Spine 7: 40-46.

8. Fong SY, DuPlessis SJ, Casha S, Hurlbert RJ (2006) Design limitations of Bryan disc arthroplasty. Spine J 6: 233-241.

9. Pimenta L, McAfee PC, Cappuccino A, Bellera FP, Link HD (2004) Clinical experience with the new artificial cervical PCM (Cervitech) disc. Spine $\mathrm{J} 4$ : 315S-321S.

10. Rabin D, Bertagnoli R, Wharton N, Pickett GE, Duggal N (2009) Sagittal balance influences range of motion: an in vivo study with the ProDisc-C. Spine J 9: 128-133.

11. Malham GM, Parker RM, Ellis NJ, Chan PG, Varma D (2014) Cervical artificial disc replacement with ProDisc-C: clinical and radiographic outcomes with longterm follow-up. J Clin Neurosci 21: 949-953.

12. Heidecke V, Burkert W, Brucke M, Rainov NG (2008) Intervertebral disc replacement for cervical degenerative disease--clinical results and functional outcome at two years in patients implanted with the Bryan cervical disc prosthesis. Acta Neurochir (Wien) 150: 453-459.

13. Murrey D, Janssen M, Delamarter R, Goldstein J, Zigler J, et al. (2009) Results of the prospective, randomized, controlled multicenter Food and Drug Administration investigational device exemption study of the ProDisc-C total disc replacement versus anterior discectomy and fusion for the treatment of 1-level symptomatic cervical disc disease. Spine J 9: 275-286.

14. Dalury DF, Jiranek WA (2004) The incidence of heterotopic ossification after total knee arthroplasty. J Arthroplasty 19: 447-452.

15. Balboni TA, Gobezie R, Mamon HJ (2006) Heterotopic ossification: Pathophysiology, clinical features, and the role of radiotherapy for prophylaxis. Int J Radiat Oncol Biol Phys 65: 1289-1299.

16. Riedel B (1883) Demonstration line durch ach Hagiges Umhergehen tota destruirten kniegelenkes von einem patienten mit stichverletzing des ruckans. Verh Dtsch Gesellschaft Chirurg 12: 93.

17. Cipriano CA, Pill SG, Keenan MA (2009) Heterotopic ossification following traumatic brain injury and spinal cord injury. J Am Acad Orthop Surg 17: 689697.

18. Déjerine A, Ceillier A (1918) Para-ostéo-arthropathies des paraplégiques par lésion médullaire; étude clinique et radiographique. Ann Med 5: 497.

19. Leung C, Casey AT, Goffin J, Kehr P, Liebig K, et al. (2005) Clinical significance of heterotopic ossification in cervical disc replacement: a prospective multicenter clinical trial. Neurosurgery 57: 759-763.

20. Anderson CL, Whitaker MC (2012) Heterotopic ossification associated with recombinant human bone morphogenetic protein-2 (infuse) in posterolateral lumbar spine fusion: a case report. Spine (Phila Pa 1976) 37: E502-506.

21. Chen J, Wang X, Bai W, Shen X, Yuan W (2012) Prevalence of heterotopic ossification after cervical total disc arthroplasty: a meta-analysis. Eur Spine J 21: $674-680$.

22. Kerr EJ, Jawahar A, Kay S, Cavanaugh DA, Nunley PD (2009) Implant design may influence delayed heterotopic ossification after total disk arthroplasty in lumbar spine. Surg Neurol 72: 747-751.

23. Lee JH, Jung TG, Kim HS, Jang JS, Lee SH (2010) Analysis of the incidence and clinical effect of the heterotopic ossification in a single-level cervical artificial disc replacement. Spine J 10: 676-682.

24. Lee SE, Chung CK, Jahng TA (2012) Early development and progression of 
Citation: Maida G, Gennaro P, Marcati E (2014) Heterotopic Ossification in the Cervical Total Disc Replacement with Discover Prostheses: A Retrospective 5-Year Follow-Up Study. J Spine 3: 194. doi:10.4172/2165-7939.1000194

heterotopic ossification in cervical total disc replacement. J Neurosurg Spine 16: 31-36.

25. Park SJ, Kang KJ, Shin SK, Chung SS, Lee CS (2011) Heterotopic ossification following lumbar total disc replacement. Int Orthop 35: 1197-1201.

26. Maida G, Marcati E, Sarubbo S (2012) Heterotopic ossification in vertebral interlaminar/interspinous instrumentation: report of a case. Case Rep Surg 2012: 970642.

27. Miao J, Shen Y, He N, Kuang Y, Wang X, et al. (2013) Clinical and radiographic outcomes of cervical disc replacement with a new prosthesis. The Spine Journal S1529-9430: 1360-1362.

28. Robinson RA, Smith GW (1955) Anterolateral cervical disc removal and interbody fusion for cervical disc syndrome. Bull Johns Hopkins Hosp 96: 223224.

29. McAfee PC, Cunningham BW, Devine J, Williams E, Yu-Yahiro J (2003) Classification of heterotopic ossification $(\mathrm{HO})$ in artificial disk replacement. $J$ Spinal Disord Tech 16: 384-389.

30. Robertson JT, Papadopoulos SM, Traynelis VC (2005) Assessment of adjacentsegment disease in patients treated with cervical fusion or arthroplasty: a prospective 2-year study. J Neurosurg Spine 3: 417-423.

31. Barrey C, Champain S, Campana S, Ramadan A, Perrin G, et al. (2012) Sagittal alignment and kinematics at instrumented and adjacent levels after total disc replacement in the cervical spine. Eur Spine J 21: 1648-1659.

32. Ahn PG, Kim KN, Moon SW, Kim KS (2009) Changes in cervical range of motion and sagittal alignment in early and late phases after total disc replacement: radiographic follow-up exceeding 2 years. J Neurosurg Spine 11: 688-695.

33. Anakwenze OA, Auerbach JD, Milby AH, Lonner BS, Balderston RA (2009) Sagittal cervical alignment after cervical disc arthroplasty and anterior cervica discectomy and fusion: results of a prospective, randomized, controlled trial. Spine 34: 2001-2007

34. Du J, Li M, Liu H, Meng H, He Q, et al. (2011) Early follow-up outcomes after treatment of degenerative disc disease with the discover cervical disc prosthesis. Spine J 11: 281-289.

35. Li J, Liang L, Ye XF, Qi M, Chen HJ, et al. (2013) Cervical arthroplasty with
Discover prosthesis: clinical outcomes and analysis of factors that may influence postoperative range of motion. Eur Spine J 22: 2303-2309.

36. Kim SW, Paik SH, Castro PA, Baek SW, Shin DJ, et al. (2010) Analysis of factors that may influence range of motion after cervical disc arthroplasty. Spine J 10: 683-688.

37. Bryan VE (2002) Cervical motion segment replacement. Eur Spine J 11(2 Suppl): S92-S97.

38. Pickett GE, Rouleau JP, Duggal N (2005) Kinematic analysis of the cervical spine following implantation of an artificial cervical disc. Spine (Phila Pa 1976) 30: 1949-1954.

39. Puzas JE, Miller MD, Rosier RN (1989) Pathologic bone formation. Clin Orthop Relat Res : 269-281.

40. Ekelund A, Brosjö O, Nilsson OS (1991) Experimental induction of heterotopic bone. Clin Orthop Relat Res : 102-112.

41. Parkinson JF, Sekhon LH (2005) Cervical arthroplasty complicated by delayed spontaneous fusion. Case report. J Neurosurg Spine 2: 377-380.

42. Heller JG, Sasso RC, Papadopoulos SM, Anderson PA, Fessler RG, et al. (2009) Comparison of BRYAN cervical disc arthroplasty with anterior cervical decompression and fusion: clinical and radiographic results of a randomized controlled, clinical trial Spine 34: 101-107.

43. Jin YJ, Park SB, Kim MJ, Kim KJ, Kim HJ (2013) An analysis of heterotopic ossification in cervical disc arthroplasty: a novel morphologic classification of an ossified mass. Spine J 13: 408-420.

44. Yi S, Kim KN, Yang MS, Yang JW, Kim H, et al. (2010) Difference in occurrence of heterotopic ossification according to prosthesis type in the cervical artificial disc replacement. Spine (Phila Pa 1976) 35: 1556-1561.

45. Suchomel P, Jurák L, Benes V 3rd, Brabec R, Bradác O, et al. (2010) Clinica results and development of heterotopic ossification in total cervical disc replacement during a 4-year follow-up. Eur Spine J 19: 307-315.

46. Tu TH, Wu JC, Huang WC, Guo WY, Wu CL, et al. (2011) Heterotopic ossification after cervical total disc replacement: determination by $\mathrm{CT}$ and effects on clinical outcomes. J Neurosurg Spine 14: 457-465. 